\title{
Synthetic Antioxidants and Its Effects in Ultra Low Concentrations, Probability of Cardio Protection by Membrane Stabilization
}

\author{
ZR Khaybullina* \\ "Auctioneer Society" Republican Specialized Center of Surgery named after Academician V.Vakhidov and Tashkent Pediatrician Medical Institute, \\ Tashkent, Uzbekistan
}

Submission: March 09, 2017; Published: April 19, 2017

*Corresponding author: ZR Khaybullina, "Auctioneer Society” Republican Specialized Center of Surgery named after academician V.Vakhidov, Uzbekistan, Tel: +998 94 6440238; Email: zrkhaybullina1@gmail.com

\section{Oxygen-Sensing Mechanism}

Oxygen-sensing mechanisms are one of the most important for cell and tissue homeostasis, as well as to adapt to the chronic low-oxygen condition, but intensive production of reactive oxygen species (ROS) can cause cell destruction. Endogenous antioxidant system protects from ROS overproduction, exogenous antioxidants in ultra low concentrations have protective effects too [1]. Detection of ability of biologically active substances (BAS) to modify live systems in ultra low concentration $\left(10^{-22}-10^{-14} \mathrm{M}\right)$, is one of the most impressing investments of last decades $[2,3]$. The specificities of influence of ultra low doses (ULD) of biologically active substances is complex and polymodal dependence of effect on dose; kinetic paradoxes; dependence of reaction on initial characteristics of biological object; «stratification» of effect (there are no effect in average doses, effect present only in $10^{-1}-10^{-3} \mathrm{M}$ and $10^{-10_{-}}$ $10^{-22} \mathrm{M}$ ); increase in sensitivity of biological objects after ULD action to influence of other physical and chemical factors [3].

Mechanisms of these phenomena are actively investigated. It is a fact, that limitation of the sizes of the some substance and ULD leads to change of its physical and chemical characteristic such as charge, magnetization and demagnetizing, the phenomena of transfer of heat, conditions for phase and structural transformations; transmission and reflex of light spectrum and etc. Thus all fundamental characteristics of substance are changed: lattice parameters, an electronic spectrum, energy of electron detachment from an external energetic membrane, temperature of fusion and etc. Forces of an attraction and aspiration to lower free energy create preconditions for self-organizing and self-assemblage of ultra small objects and structures, and the nature widely uses with it, especially in biological objects [4]. It has been shown, that at ultralow concentration the specific molecules of substance can form supramolecular nanodimensional particles, which can be considered as hydrophilic surfaces, and a target of their action in biological objects can be as membrane structures. Natural and synthetic antioxidants concern that type of agents which possess this ability [4]. Water soluble synthetic antioxidant Phenozan (space labored phenols group) has been synthesized in Institute chemical physicists (Russia). It is strong antioxidant influencing on structure and functions of membranes. Biologically significant targets of Phenozan are micro domains of liposome, fragments of a cellular membrane, superficial cellular receptors and cellular organelle, also system of signal transduction, reparation and apoptosis of cells. Phenozan in concentration $10^{-14} \mathrm{M} / \mathrm{kg}$ increased life expectancy in leucosis mouses (Erohin A., 2008), Phenozan can stabilize DNA-molecule by decreasing of its breaks after radiation, so it can be used as radio protector. Phenozan in ULD have ability to block purines receptors (PY2) and calcium channels (CRAC), so it have influence to the signal transduction system of the cell [2]. Phenozan can modify activity of some enzymes-membrane-binded and soluble acetyl cholinesterase, proteinkinase $\mathrm{C}$, lactatdehydrogenase (LDG), superoxiddismutase (SOD), glutationperoxidase. Mitochondrial enzymes are more sensitive to Phenozan, vs cytoplasm enzymes [4] Phenozan can modify activity of LDG in brain microsomes in vivo, increase activity of glutationS-transferase, decrease NO-production in macrophages [5]. Phenozan leads activation of anti-apoptotic proteins bcl2 and p53 [3]. We have discovered ability of Phenozan to decrease oxidation of brain phospholipids in dose $10^{-16} \mathrm{M} / \mathrm{kg}$ in newborn rats after experimental chronic fetal hypoxia [6]. Phenozan in ULD leads to statistically significant $(\mathrm{p}<0,01)$ decrease of MDA level and increase of the ROS scavenger enzymes in a brain, peripheral blood and in microsomal and 
mitochondrial fractions of the liver at this experiment. During treatment with 10 enteral doses of Phenozan $\left(10^{-16} \mathrm{M} / \mathrm{kg}\right)$ in brain tissues observed the normalization of SOD activities (on $5^{\text {th }}$ day), katalase activities (on $8^{\text {th }}$ day), level of MDA (on $10^{\text {th }}$ day). We suppose that treatment with ULD of Phenozan cause decreasing of ROS generation in brain tissues at critical periods of its development in newborn rats [6]. Significance of this data support that ultra low doses of Phenozan can be less invasive and effective in the treatment of chronic intrauterine hypoxia and suggest the directions for further research of its membranoprotective effects in cardiology.

Cytoprotective and cardioprotective effect was founded at serin proteases inhibitor Aprotinin in a prospective, randomized, double-blind, placebo-controlled trial: low-dose postoperative aprotinin reduces mediastinal drainage and blood product use in patients undergoing primary coronary artery bypass grafting, in ULD Aprotinin causes modulation of antithrombotic enzymes and leads decreasing of transfusional complications [7]. Oxidative stress and apoptosis are major mechanisms of cell damage at hypoxia, which is common at cardiovascular diseases [8]. So, ULD of antioxidants have approved positive membrane stabilizing effects, they are potential cyto-protectors, which may be tried in cardioprotection for cardiomyocytes membrane stabilization.

(Memories of my teachers - academician U.K. Ibragimov and E.B.Burlakova is denoted).

\section{References}

1. Nazirov FG, Ibragimov UK, Khaybullina ZR (2014) Biological effects of reactive oxygen species and antioxidants. Lap Lambert Academic publishing, Germany, pp. 114.

2. Alekseeva OM, Kim Yu A, Mil EM (2010) Comparative investigation influence of hybrid antioxidants on the structure and functions of biological membranes. International Conference "Bioantioxidant", Moscow, Russia, p. 16-17.

3. Burlakova EB, Konradov AA, Mal'tseva EL (2007) The Effect of Ultra Low Doses of Biologically Active Substances and Low Rate Physical Factors. LIFE and MIND -In Search of the Physical Basis. Misaha SS (Ed), Trafford Publishing, USA, pp. 79-113.

4. (2008) IY International Symposium "Mechanisms of action ultra low doses" Moscow, Russia, pp. 160.

5. Burlakova EB, Goloshapov AN, Yu AT (2003) Effects of ultra low doses of Phenozan on biochemical properties of lactatedehydrogenase and micro viscosity of brain's micrososmes membranes. Radiation biology. Radioecology 3: 320-323.

6. Khaybullina ZR (2011) Intrauterine hypoxia of fetus-influence of ultralow doses of antioxidant (experimental research). Medical and Health Science Journal 8(4): 41-49.

7. Nazirov FG, Khaybullina ZR, Kosnikova IV, Kim VH (2016) Inflammation and reactive oxygen species generation at the peripheral and coronary atherosclerosis, comparative evaluation of its intensity and grade. American Journal of Cardiovascular and Thoracic Surgery 1(1): 5.

8. Alvarez JM, Jackson LR, Chatwin C, Smolich JJ (2001) Low-dose postoperative aprotinin reduces mediastinal drainage and blood product use in patients undergoing primary coronary artery bypass grafting who are taking aspirin: A prospective, randomized, doubleblind, placebo-controlled trial. J Thorac Cardio Surg 122(3): 457-463.

\section{Your next submission with Juniper Publishers} will reach you the below assets

- Quality Editorial service

- Swift Peer Review

- Reprints availability

- E-prints Service

- Manuscript Podcast for convenient understanding

- Global attainment for your research

- Manuscript accessibility in different formats

( Pdf, E-pub, Full Text, Audio)

- Unceasing customer service

Track the below URL for one-step submission https://juniperpublishers.com/online-submission.php 